\title{
Evaluation of the Effects of Nigerian Portland-Limestone Cement Grades on the Strength of Concrete
}

\author{
V. O. Okonkwo, I. K. Omaliko, and C. U. Chidolue
}

\begin{abstract}
The influence of Nigerian Portland-Limestone cement grades on the strength of concrete was investigated in this study. Three cement grades of 32.5R, 42.5R and 42.5N were adopted. A constant mix design ratio of $1: 2: 4$ with a varying water-cement ratio of $0.4,0.5$, and 0.6 was used. All of the constituents of concrete were calculated using the mass of a concrete cube specimen of $150 \mathrm{~mm} \times 150 \mathrm{~mm} \times 150 \mathrm{~mm}$. A total of 135 cube specimens were cast and cured for $3,7,14$, 21 and 28 days accordingly in order to determine the compressive strength of the concrete. The results obtained show that concrete cube specimens produced with PortlandLimestone cement grade $42.5 \mathrm{~N}$ had the optimum compressive strength on the 28th day of curing in each water-cement ratio. However, the optimum compressive strength on the 7th day of curing in each water-cement ratio was obtained in the concrete cube specimens produced with Portland-Limestone cement grade 42.5R. The results also show that concrete produced from cement grade 32.5 will generally produce more workable but weaker concrete than concrete produced from cement grade 42.5, irrespective of the water-cement ratio. Finally, it was concluded that the compressive strength of concrete is inversely proportional to all the water-cement ratios used in this study, irrespective of the grade of cement.
\end{abstract}

Keywords - Concrete, Cement Grades, PortlandLimestone Cement, Compressive Strength.

\section{INTRODUCTION}

Concrete is the most commonly used material in the construction industry since it is utilized to construct the majority of infrastructure designs such as bridges, buildings, drainages, roads, seaports, harbours, runways, etc. [1]. The strength, structural integrity, and safety of concrete construction are heavily reliant on the quality of concrete utilized. The concrete utilized in construction is typically made from cement, aggregate and water. Coarse and fine aggregate are utilized in concrete production, while cement acts as the binder in the presence of water, which initiates the hydration process [2]. Cement is the sole industrially manufactured ingredient of concrete, as well as the most expensive ingredient in a cubic meter of concrete, and its properties have the greatest influence on the properties of concrete [3].

The strength of concrete is mainly determined by the quality and quantity of cement, which acts as the primary strength provider in concrete by cementing the fine and coarse aggregate together to produce a rigid mass capable of

\footnotetext{
Submitted on January 28, 2022.

Published on March 04, 2022.

V. O. Okonkwo, Civil Engineering Department, Nnamdi Azikiwe University, Nigeria.

(e-mail: vo.okonkwo@unizik.edu.ng)
}

sustaining load [4].

Because of the numerous building collapses in Nigeria, either during construction or in service, with accompanying loss of life and property, the concrete sector has garnered persistent attention in recent years. [5] estimated that about $90 \%$ of the identified reasons are structural related. Because concrete is used to construct the majority of structures in Nigeria, it is appropriate to study concrete as a material while simultaneously questioning the quality of its various constituents. Furthermore, the majority of buildings in Nigeria are owned by ordinary people who cannot afford to hire skilled engineers to build their structures. Consequently, about $70 \%$ of structures in Nigeria are built by artisans [1] They usually adopt a 1:2:4 mix ratio regardless of the cement grade since they are uninformed of the availability of different grades of cement in Nigeria and their impact on the strength of concrete. The fact that the costs of the available grades of cement in the Nigerian market are all the same doesn't help either.

Generally, most Nigerians purchase and utilize cement based on brand names rather than cement grades. Aside from a lack of knowledge about the various cement grades in Nigeria, most Nigerian artisans, engineers, and researchers still assume that the bagged Portland-Limestone Cement (PLC) in the open market is the same as the ordinary Portland Cement (OPC). They are unaware that the OPC adhering to the CEM I class of cement, which was the only cement type permitted in Nigeria under the previous Nigerian industrial standards for cement: [6] and [7], is no longer in existence in a bagged form in Nigeria. In Nigeria, OPC is only manufactured in large quantities at the request of large construction corporations handling large projects. Portlandlimestone cement has been the sole bagged cement available in the Nigerian open market since 2003 [8].

Ordinary Portland cement, often known as Portland cement, is the cement that contains $95-100 \%$ clinker and gypsum. However, Portland-limestone cement is the only cement accessible in the open market, and [9] designates it as a CEM II class of cement. It is a type of common cement known as Portland-composite cement, which is a general term for Portland cement. Unlike OPC, which is primarily made up of clinker and gypsum, Portland-limestone cement is made by combining OPC with 6-35\% limestone [10]. As a result, Portland-limestone cement has a lower clinker concentration than OPC, ranging from 65 to $94 \%$ clinker. Clinker is the primary component of cement that provides the strength [11].

\footnotetext{
I. K. Omaliko, Civil Engineering Department, Nnamdi Azikiwe University, Nigeria.

(e-mail: ik.omaliko@unizik.edu.ng).

C. U. Chidolue, Nnamdi Azikiwe University, Nigeria.
} 
Limestone is added to OPC to manufacture Portlandlimestone cement because it is simpler to process and less expensive than clinker. It also has a lesser carbon footprint than OPC and it is more environmentally friendly [12], [13].

The most significant and regularly utilized cement in the construction industry is PLC and OPC. They are primarily classified into three types, as specified by [14] as 33-Grade Cement, 43-Grade Cement, and 53-Grade Cement. The minimum 28th-day compressive strength of the cement, also known as cement strength classes of $32.5 \mathrm{MPa}, 42.5 \mathrm{MPa}$, and 52.5 $\mathrm{MPa}$ respectively, is used to define these cement grades [15]. The cement classes are further classified in terms of strength as $32.5 \mathrm{~N}, 32.5 \mathrm{R}, 42.5 \mathrm{~N}, 42.5 \mathrm{R}, 52.5 \mathrm{~N}$, and 52.5 $\mathrm{R}$. After 28 days, the 32.5 grade must have a strength range of $32.5 \mathrm{~N} / \mathrm{mm}^{2}$ to $52.5 \mathrm{~N} / \mathrm{mm}^{2}$, whereas the 42.5 grade must have a strength range of $42.5 \mathrm{~N} / \mathrm{mm}^{2}$ to $52.5 \mathrm{~N} / \mathrm{mm}^{2}$. The third category's minimum strength is $52.5 \mathrm{~N} / \mathrm{mm} 2$ [13].

The suffix "N" denotes cement with normal early strength, whereas "R" denotes cement with significant early strength [16]. According to Hawkins, Tennis and Detwiler [17], the fineness (specific area) of 33-Grade Cement is $300 \mathrm{~m}^{2} / \mathrm{kg}$. This cement grade has good workability and is mostly utilized for masonry, tiling, and plastering projects. It is commonly utilized where a concrete grade of up to M20 is required. Its hydration heat is less than that of other cement grades. 43Grade Cement, on the other hand, has a fineness of $225 \mathrm{~m}^{2} / \mathrm{kg}$ and provides good concrete workability. It has a low chloride content; therefore it does not corrode steel reinforcement. 43Grade cement has a medium heat of hydration. It is utilized in precast and pre-stressed concrete, as well as in the construction and finishing of various kinds of structures such as water-retaining structures, bridges, highways, and buildings. It is commonly utilized in construction where a concrete grade of up to M30 is required.

However, 53-Grade Cement is known for its high quality and durability. It is commonly utilized in projects requiring more strength, such as concrete bridges, industrial buildings, runways, highways, pre-stressed girders, etc. It is typically used for concretes of M25 and above. Its fineness is $225 \mathrm{~m}^{2} / \mathrm{kg}$. It is the cement that is resistant to sulphates and has a low chloride concentration. Because it acquires early strength, it speeds up construction and also saves money on shuttering because of early removal [17]. Only cement grades 33 and 43 are accessible for construction in the Nigerian open market, which engineers use to get an acceptable concrete mix design for individual works. Both grades of cement, according to COREN [18], are appropriate for construction work.

Findings from the studies carried out by Hodhod and Abdeen [19], Mathur, Misra and Goel [20], have shown that in Ordinary Portland Cement, the stronger the cement grade, the stronger the concrete compressive strength, provided the mix ratio remains constant. However, due to the substitution of Portland-Limestone Cement for Ordinary Portland Cement in the Nigerian open market, Kazeem, Festus and Hamzat [21] studied PLC grades of $32.5 \mathrm{~N}$ and $42.5 \mathrm{~N}$ commonly used for concrete production in Nigeria. In the investigation, different mix ratios related to building construction were utilized. When the 28-day compressive strength values of concrete generated with the two PLC grades were compared, it was discovered that PLC grade $42.5 \mathrm{~N}$ produced stronger concrete than PLC grade $32.5 \mathrm{~N}$ in all the mix ratios used.

Adewole, Ajagbe and Arasi [8] conducted a study using Portland-Limestone Cement grades 32.5 and 42.5. It was discovered that the concrete produced from PLC grade 42.5 was stronger than the concrete produced from PLC grade 32.5. However, as the mix was changed from $1: 2: 4$ to $1: 1: 2$ in order to increase the cement concentration, the difference in concrete strengths produced by both grades of cement decreased. As a result, it was established that the stronger the concrete grade, the less relevant the cement grade. Furthermore, a cement grade of 32.5 in a 1:2:4 mix cannot be used to produce a concrete of strength class M20/25, which is the minimum concrete strength class recommended for the construction of load-bearing structural elements, but rather with a cement grade of 42.5 .

The present study aims at evaluating the effects of cement grades on the compressive strength characteristics of structural concrete made from Nigerian Portland-Limestone cement grades of $32.5 \mathrm{R}, 42.5 \mathrm{R}$ and $42.5 \mathrm{~N}$.

\section{MATERIALS AND METHODS}

\section{A. Materials}

The cement utilized in this study was locally manufactured Nigerian Portland-Limestone cement of grades 32.5R, 42.5R, and $42.5 \mathrm{~N}$. A crushed aggregate of normal weight and irregular shape with a maximum size of $20 \mathrm{~mm}$ and sharp sand finer than $4.75 \mathrm{~mm}$ sieve size were used in all of the concrete mixes. For the mixing of concrete, portable water was utilized.

\section{B. Mix Design}

A fixed cement-sand-granite mix design ratio of 1:2:4 of concrete grade M20 was used for all the cement grades, with a varied water-cement ratio of $0.4,0.5$ and 0.6. The mass of the concrete cube specimen of $150 \mathrm{~mm} \times 150 \mathrm{~mm} \times 150 \mathrm{~mm}$ was used to calculate all of the constituents of concrete. Three concrete specimens were cast per water-cement ratio, per grade of cement and per curing time.

\section{Test Methods}

All tests were performed at the material testing laboratory of the Department of Civil Engineering, Nnamdi Azikiwe University, Awka, Nigeria. Tests were conducted on the raw materials and also on both the fresh and hardened concrete in accordance with their respective standards.

\section{1) Sieve analysis test}

The sieve analysis, also known as the gradation test, was performed to evaluate the gradation of the fine aggregate particles by size in order to determine design compliance and aggregate suitability. This test was conducted using a mechanical shaker in line with BS EN 933-2 [22] standards.

\section{2) Fineness test}

The particle size of the cement was determined using the fineness test. The cement sample was sieved via a standard IS sieve in line with [23]. The weight of cement particles larger than 90 microns was determined, and using (1), the percentage of retained cement particles was computed. 
$\%$ of cement retained $=\frac{\text { The mass retained on the sieve }(\mathrm{w} 2)}{\text { mass of cement }(\mathrm{w} 1)} \times 100$

(1)

\section{3) Test on fresh concrete}

A slump flow test was performed after the concrete casting process was completed to assess the workability of the fresh concrete. The test was carried out in accordance with the BS EN 12350-2 [24] specification using a $305 \mathrm{~mm}(\mathrm{~h}) \times$ $203 \mathrm{~mm}$ (b) frustum with a $102 \mathrm{~mm}$ diameter opening at the top.

\section{4) Test on hardened concrete}

Compressive strength is the maximum compressive stress that a particular solid material can withstand without fracturing under a gradually applied load [25]. The compressive strength test was performed on the hardened concrete cube specimens. The test was performed after each curing time of 3, 7, 14, 21 and 28 days. The specimens were taken out of the water and allowed to dry. After the specimens had dried, they were weighed and tested. For the determination of the compressive strength, a total of 135 cube specimens of $150 \mathrm{~mm} \times 150 \mathrm{~mm} \times 150 \mathrm{~mm}$ were cast, cured, and tested accordingly in accordance with [26]

A compressive testing machine was utilized to assess the compressive strength of the cube specimens. The specimen was centred on the compression machine's location marks, delivering the load to the opposing sides of the cube cast. The load was gradually and consistently applied at a rate of $2 \mathrm{kN} / \mathrm{Sec}$ until the specimen failed. The ultimate compressive load at which the specimen collapsed was then recorded. The compressive strength, $\mathrm{Fc}$, of each cube was estimated using (2) based on the ultimate load and surface area in contact with the platens.

$$
\mathrm{F}_{\mathrm{c}}=\frac{\text { Average Ultimate Load }(\mathrm{KN})}{\text { Surface Area }\left(\mathrm{mm}^{2}\right)}=\frac{\mathrm{F}_{\mathrm{ult}}}{\mathrm{A}}
$$

\section{RESULTS AND DISCUSSIONS}

The sieve analysis of the fine aggregate, the slump of the fresh concrete, and the compressive strength of the concrete specimens were determined and reported in Tables I, II and III, respectively.

\section{A. Sieve Analysis}

TABLE I: SIEVE ANALYSIS TEST RESULT

\begin{tabular}{ccccc}
\hline $\begin{array}{c}\text { Sieve } \\
\text { Size }\end{array}$ & $\begin{array}{c}\text { Mass } \\
\text { Retained }\end{array}$ & $\begin{array}{c}\% \\
\text { Weight } \\
\text { Retained }\end{array}$ & $\begin{array}{c}\text { Cumulative } \\
\text { Percentage } \\
\text { Retained }\end{array}$ & $\begin{array}{c}\text { Cumulative } \\
\text { Percentage } \\
\text { Passing }\end{array}$ \\
\hline 2 & 7.26 & 1.82 & 1.82 & 98.18 \\
1.18 & 16.79 & 4.20 & 6.02 & 93.98 \\
1 & 10.92 & 2.73 & 8.75 & 91.25 \\
0.6 & 57.88 & 14.48 & 23.23 & 76.77 \\
0.3 & 197.26 & 49.36 & 72.59 & 27.41 \\
0.15 & 92.68 & 23.19 & 4.22 & 95.78 \\
0.075 & 14.54 & 3.64 & 99.42 & 0.58 \\
Tray & 2.30 & 0.58 & 0.00 & 100 \\
& 399.63 & & & \\
\hline
\end{tabular}

From Fig. 1, the coefficient of curvature was determined using (3). It was discovered that it had a value that is less than one. Hence, the fine aggregate was classified as poorly graded sand.

$$
C_{c}=\frac{(D 30)^{2}}{D 60 \times D 10}
$$

where $C_{C}$ is the Coefficient of curvature, $D 30$ is the size at which $30 \%$ is finer by weight and the remaining $70 \%$ particles are coarser than D30, D60 is the particle size at which $60 \%$ of the particles are finer and $40 \%$ of the particles are coarser than D60 size, D10 is the effective particle size. It is also the particle size at which $10 \%$ of the particles are finer and $90 \%$ of the particles are coarser than D10.

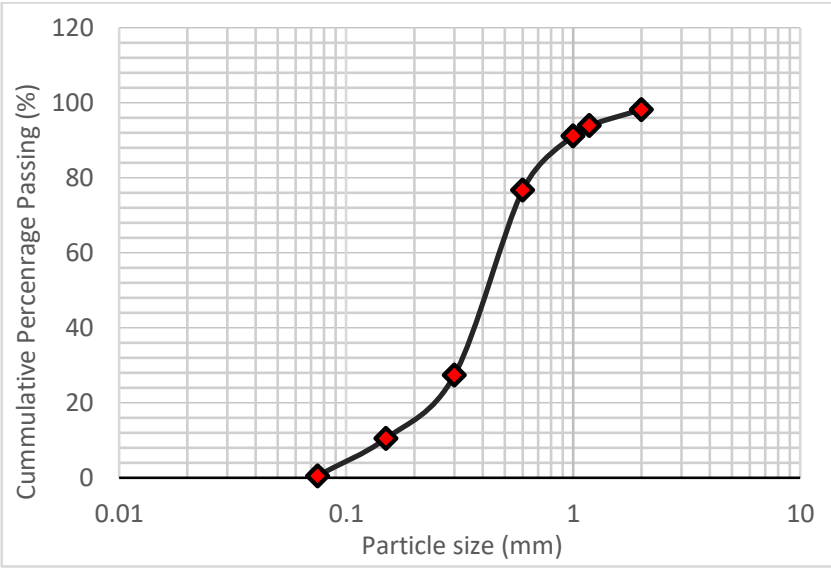

Fig. 1. Particle size distribution curve of the fine aggregate.

\section{B. Slump}

\begin{tabular}{|c|c|c|c|}
\hline \multirow[b]{2}{*}{$\begin{array}{c}\text { Water-Cement } \\
\text { Ratio }\end{array}$} & \multicolumn{3}{|c|}{ Slump (mm) } \\
\hline & $\begin{array}{c}\text { Cement } \\
\text { Grade } 32.5 \mathrm{R} \\
\end{array}$ & $\begin{array}{c}\text { Cement } \\
\text { Grade } 42.5 \mathrm{R}\end{array}$ & $\begin{array}{c}\text { Cement } \\
\text { Grade } 42.5 \mathrm{~N}\end{array}$ \\
\hline 0.4 & 35 & 28 & 30 \\
\hline 0.5 & 45 & 40 & 43 \\
\hline 0.6 & 85 & 80 & 85 \\
\hline
\end{tabular}

TABLE II: SLump Test Result FOR All THE CEMENT GRADES

From Fig. 2, it can be observed that the workability of the concrete produced with all the cement grades $(32.5 \mathrm{R}, 42.5 \mathrm{R}$, and $42.5 \mathrm{~N}$ ) increased as the water-cement ratio increased from 0.4 to 0.6 . This observed tendency, according to [27]; $\mathrm{Vu}$ et al. [28], can be attributed to the fact that the higher the Water-Cement ratio of a given mix, regardless of cement grade, the higher the water content per volume of concrete, which improves the workability of fresh concrete. The concrete produced with Cement Grade 32.5R had the best workability in all the Water-Cement ratios when compared with other cement grades. However, optimum workability of $85 \mathrm{~mm}$ was obtained in both the concrete produced with Cement Grade $32.5 \mathrm{R}$ and $42.5 \mathrm{~N}$ using a water-cement ratio of 0.6. While Cement Grade 42.5R exhibited the lowest slump in all the Water-Cement ratios.

Based on BS EN 12350-2 classification, low workability concrete was obtained in all the grades of cement with 0.4 and 0.5 water-cement ratio, while concrete of medium workability was obtained in all the cement grades with a 0.6 water-cement ratio. The result shows that the slumps obtained at 0.4 and 0.5 water-cement ratios are true slumps, while the slump obtained at 0.6 water-cement ratio is a shear slump. 


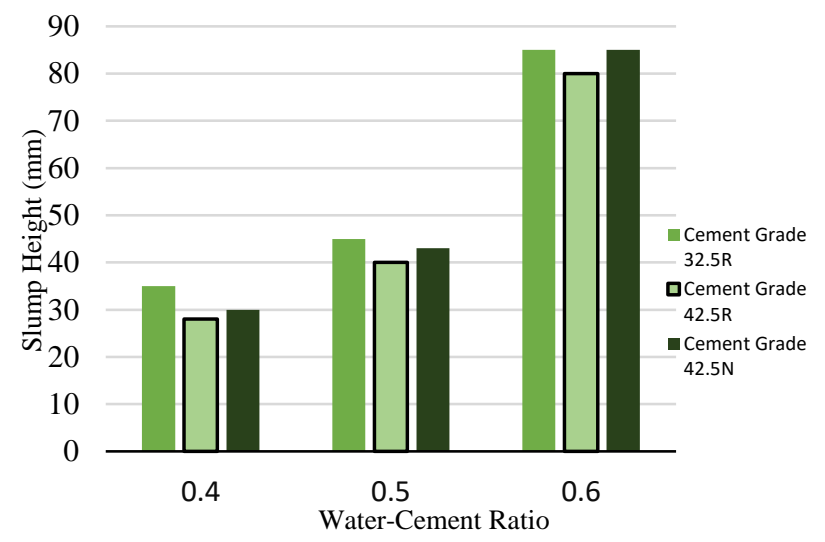

Fig. 2. A comparison of the effects of various water-cement ratios on the slump of concrete produced with various cement grades.

\section{Compressive Strength}

From Fig. 3, 4 and 5, it can be observed that the compressive strength of concrete produced with all the cement grades $(32.5 \mathrm{R}, 42.5 \mathrm{R}$, and $42.5 \mathrm{~N})$ decreased as the water-cement ratio increased from 0.4 to 0.6 . According to [27], $\mathrm{Vu}$ et al. [28], this observed trend can be attributed to the fact that the higher the Water-Cement ratio of a given mix, regardless of cement grade, the higher the water content per volume of concrete, which improves the compressive strength of the hardened concrete. This is evident because the water-cement ratio of 0.4 gave the optimum concrete compressive strength of all the cement grades in all the curing times, while the lowest concrete compressive strength was recorded in all the cement grades with a 0.6 water-cement ratio.

From Fig. 3, 4 and 5, it can be observed that the compressive strength of concrete produced with all the cement grades $(32.5 \mathrm{R}, 42.5 \mathrm{R}$, and $42.5 \mathrm{~N})$ decreased as the water-cement ratio increased from 0.4 to 0.6. According to [27], Vu et al. [28], this observed trend can be attributed to the fact that the higher the Water-Cement ratio of a given mix, regardless of cement grade, the higher the water content per volume of concrete, which improves the compressive strength of the hardened concrete. This is evident because the water-cement ratio of 0.4 gave the optimum concrete compressive strength of all the cement grades in all the curing times, while the lowest concrete compressive strength was recorded in all the cement grades with a 0.6 water-cement ratio.

TABLE III: COMPRESSIVE STRENGTH TEST RESUlt FOR All THE CEMENT GRADES

\begin{tabular}{|c|c|c|c|c|c|c|c|c|c|c|}
\hline \multicolumn{11}{|c|}{ CROSS SECTIONAL AREA $=150 \mathrm{~mm} \times 150 \mathrm{~mm}$} \\
\hline \multirow{3}{*}{$\begin{array}{l}\text { Cement } \\
\text { Grade }\end{array}$} & \multirow{3}{*}{$\begin{array}{l}\text { Curing Time } \\
\text { (days) }\end{array}$} & \multicolumn{3}{|c|}{$\begin{array}{c}\text { Average Weight } \\
(\mathrm{kg})\end{array}$} & \multicolumn{3}{|c|}{$\begin{array}{l}\text { Average Load } \\
(\mathrm{KN})\end{array}$} & \multicolumn{3}{|c|}{$\begin{array}{c}\text { Average Compressive } \\
\text { Strength } \\
(\mathrm{MPa})\end{array}$} \\
\hline & & $\mathrm{W} / \mathrm{C}$ & $\mathrm{W} / \mathrm{C}$ & $\mathrm{W} / \mathrm{C}$ & $\mathrm{W} / \mathrm{C}$ & $\mathrm{W} / \mathrm{C}$ & $\mathrm{W} / \mathrm{C}$ & $\mathrm{W} / \mathrm{C}$ & $\mathrm{W} / \mathrm{C}$ & $\mathrm{W} / \mathrm{C}$ \\
\hline & & 0.4 & 0.5 & 0.6 & 0.4 & 0.5 & 0.6 & 0.4 & 0.5 & 0.6 \\
\hline \multirow{5}{*}{$32.5 \mathrm{R}$} & 3 & 8.455 & 8.604 & 8.538 & 270 & 205 & 170 & 12.00 & 9.08 & 7.56 \\
\hline & 7 & 8.456 & 8.576 & 8.613 & 400 & 305 & 260 & 15.11 & 13.54 & 11.39 \\
\hline & 14 & 8.482 & 8.784 & 8.837 & 470 & 390 & 320 & 21.34 & 17.33 & 14.22 \\
\hline & 21 & 8.496 & 8.586 & 8.761 & 531 & 514 & 440 & 23.60 & 22.83 & 19.56 \\
\hline & 28 & 8.787 & 8.700 & 8.506 & 562 & 552 & 485 & 24.98 & 24.67 & 21.44 \\
\hline \multirow{5}{*}{$42.5 \mathrm{R}$} & 3 & 8.540 & 8.690 & 8.542 & 330 & 270 & 230 & 14.68 & 12.00 & 10.21 \\
\hline & 7 & 8.438 & 8.662 & 8.611 & 528 & 465 & 385 & 23.47 & 20.67 & 17.10 \\
\hline & 14 & 8.567 & 8.764 & 8.736 & 645 & 510 & 420 & 28.67 & 22.66 & 18.56 \\
\hline & 21 & 8.467 & 8.586 & 8.757 & 735 & 700 & 590 & 32.67 & 31.11 & 26.21 \\
\hline & 28 & 8.757 & 8.688 & 8.522 & 800 & 755 & 690 & 35.58 & 33.56 & 30.73 \\
\hline \multirow{5}{*}{$42.5 \mathrm{~N}$} & 3 & 8.365 & 8.351 & 8.514 & 290 & 230 & 210 & 12.81 & 10.15 & 9.26 \\
\hline & 7 & 8.414 & 8.657 & 8.604 & 507 & 420 & 375 & 22.50 & 18.57 & 16.63 \\
\hline & 14 & 8.451 & 8.847 & 8.577 & 615 & 600 & 455 & 27.27 & 26.86 & 20.24 \\
\hline & 21 & 8.496 & 8.562 & 8.753 & 735 & 705 & 610 & 32.67 & 31.26 & 27.11 \\
\hline & 28 & 8.667 & 8.721 & 8.504 & 815 & 775 & 720 & 36.21 & 34.42 & 31.99 \\
\hline
\end{tabular}

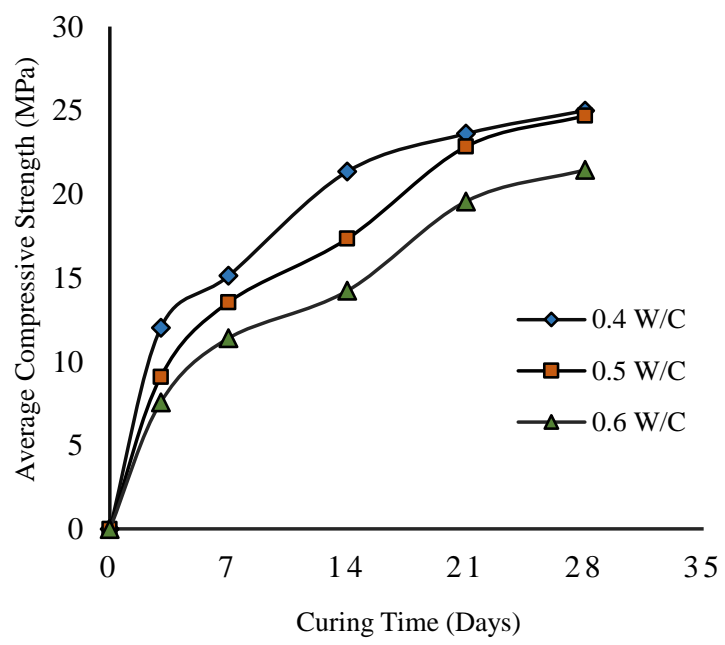

Fig. 3. Comparison of the influence of different water-cement ratios on the compressive strength of concrete produced with Cement Grade 32. 5R.

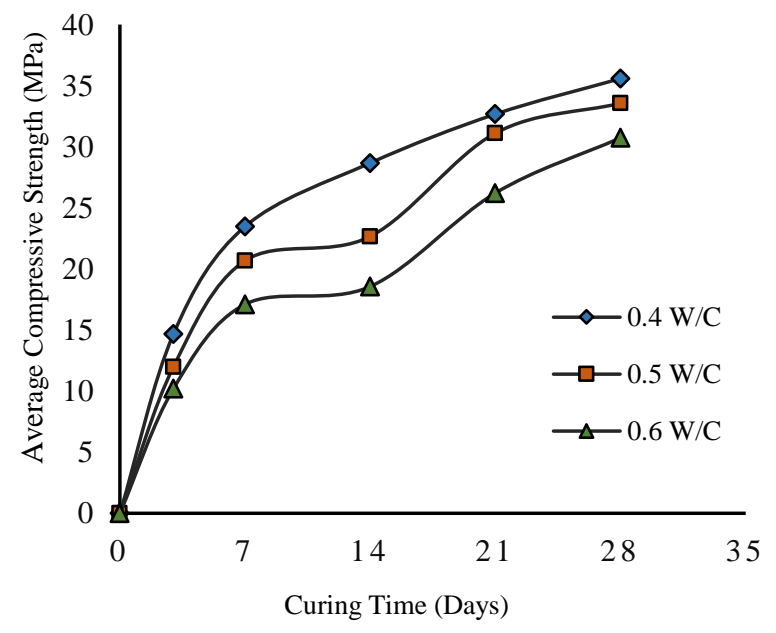

Fig. 4. Comparison of the influence of different water-cement ratios on the compressive strength of concrete produced with Cement Grade 42.5R. 


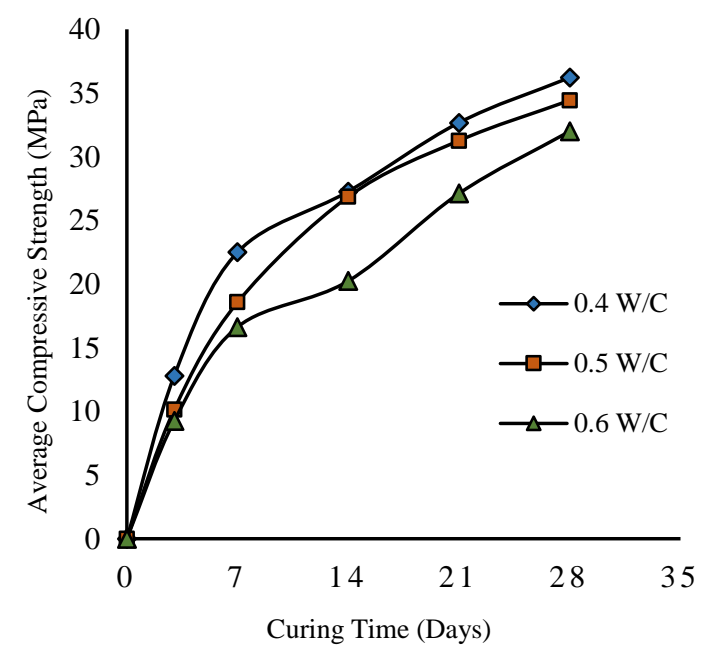

Fig. 5. Comparison of the influence of different water-cement ratios on the compressive strength of concrete produced with Cement Grade 42.5N.

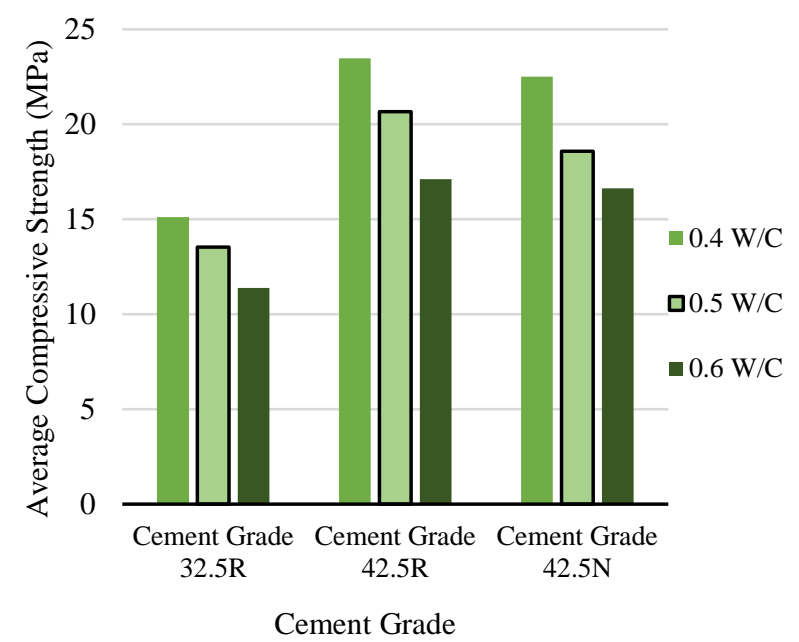

Fig. 6. A comparison of the influence of different cement grades on the $7^{\text {th }}$ day of curing on the compressive strength of concrete produced with various water-cement ratio.

From Fig. 6, it can be observed that the optimum compressive strength on the 7 th day of curing in each watercement ratio was obtained in the concrete cube specimens produced with PLC grade $42.5 \mathrm{R}$. The high early strength associated with PLC grade 42 . 5R can be attributed to its fast reaction process and its rapid hardening property as it contains more tricalcium silicate and is more finely grounded. However, the compressive strength on the 7 th day of curing in each Water-Cement ratio of the concrete cube specimens produced with Cement Grade $42.5 \mathrm{~N}$ is higher than the ones produced with $32.5 \mathrm{R}$ cement grade. This can be attributed to the fact that Cement Grade $42.5 \mathrm{~N}$ has both high early and late strength characteristics, even though it is classed as cement with ordinary early strength $(\mathrm{N})$.

The higher compressive strengths of the concrete cubes produced with grade 42.5 cement are due to the higher compressive strength of grade 42.5 cement. This is also evident in Fig. 7, where the influence of different cement grades on the $28^{\text {th }}$ day of curing on the compressive strength of concrete produced with a varied water-cement ratio is shown. It can be observed that the optimum compressive strength on the $28^{\text {th }}$ day of curing in each water-cement ratio was obtained in the concrete cube specimens produced with
PLC grade $42.5 \mathrm{~N}$. This is attributed to the late strength of Cement Grade $42.5 \mathrm{~N}$.

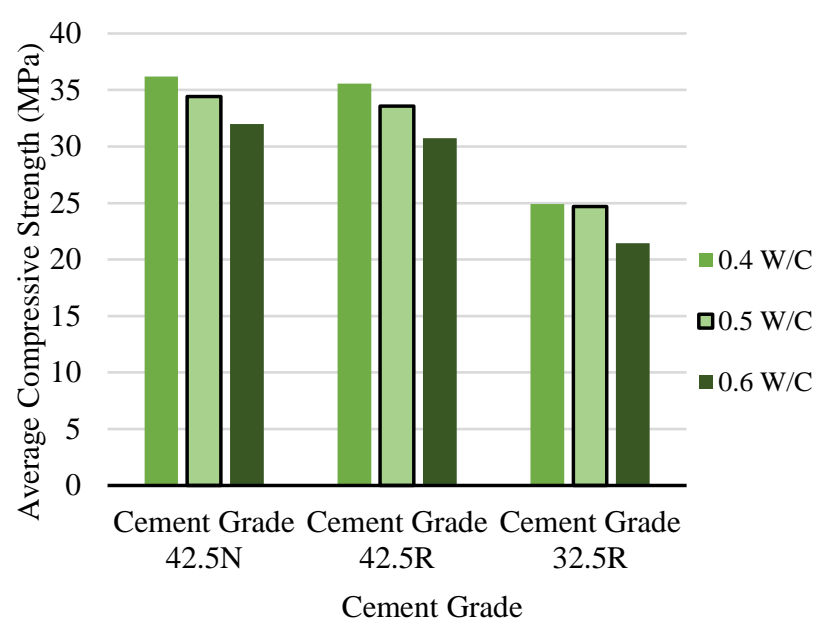

Fig. 7. A comparison of the influence of different cement grades on the 28th day of curing on the compressive strength of concrete produced with various water-cement ratio.

It is evident in both Fig. 6 and 7 that as the Water-Cement ratio was increased in all the concrete mix produced with the different cement grades, the compressive strength of the concrete cube specimens decreased. Hence, it can be said that the compressive strength of concrete is inversely proportional to the water-cement ratio, irrespective of the grade of cement used.

\section{CONCLUSION}

From the study carried out on the evaluation of the effects of Nigerian Portland-limestone cement grades on the strength of concrete, the following conclusions were reached:

1) The workability of fresh concrete is directly proportional to all the water-cement ratios used, irrespective of the grade of cement.

2) Cement Grade 32.5R generally produces fresh concrete that is more workable than Cement Grade $42.5 \mathrm{R}$ and $42.5 \mathrm{~N}$ in any Water-Cement ratio used in the study.

3) The compressive strength of concrete is inversely proportional to all the water-cement ratios used, irrespective of the grade of cement.

4) The optimum compressive strength on the 7th day of curing in each water-cement ratio was obtained in the concrete cube specimens produced with PLC grade 42.5R. Hence, it can be concluded that Cement Grade 42.5R has a high early strength characteristic than Cement Grade 32.5R and 42.5N.

5) The optimum compressive strength on the 28th day of curing in each water-cement ratio was obtained in the concrete cube specimens produced with PLC grade $42.5 \mathrm{~N}$. Hence, it can be concluded that Cement Grade 42.5R has a high late strength characteristic than Cement Grade $42.5 \mathrm{~N}$.

6) The compressive strength on the $7^{\text {th }}$ day of curing in each Water-Cement ratio of the concrete cube specimens produced with Cement Grade $42.5 \mathrm{~N}$ was higher than the ones produced with $32.5 \mathrm{R}$ cement grade. Hence, it can be concluded that Cement Grade 
$42.5 \mathrm{~N}$ has both high early and late strength characteristics even though it is classed as cement with ordinary early strength $(\mathrm{N})$.

7) Finally, concrete produced from Cement Grade 32.5 will generally produce more workable but weaker concrete than concrete produced from Cement Grade 42.5 , irrespective of the water-cement ratio.

\section{REFERENCES}

[1] Oloyede SA. Tackling causes of frequent building collapse in Nigeria. Journal of sustainable development, 2010; 3(3), p. 127-132.

[2] Emiero C, Oyedepo, OJ. An Investigation on the Strength an Workability of Concrete Using Palm Kernel Shell and Palm Kernel Fibre as a Coarse Aggregate. International Journal of Scientific and Engineering Research, 2000; vol: 3, Issue 4, p. 1-5.

[3] Barrett TJ, Sun, H, Weiss WJ. Performance of Portland limestone cements: cements designed to be more sustainable that include up to 15\%. Limestone Addit. 2013; p. 1-64.

[4] Adewoke KK, Olutoge, FA, Habib, H. Effect of Nigerian PortlandLimestone cement grades on concrete compressive strength. International Journal of Civil, Environmental, structural construction and Architectural Engineering, 2014; 8, (11):1140-1143.

[5] Odeyemi, SO, Giwa, ZT, Abdulwahab, R. Building Collapse in Nigeria (2009-2019), Causes and Remedies - A Review. Journal of Science and Engineering Production, 2019; 1(1): 122 - 135

[6] NIS 11: (1974). Specification for ordinary Portland cement, Standards Organization of Nigeria.

[7] NIS 439: (2000). Standard for cement. Standards Organization of Nigeria.

[8] Adewole, KK, Ajagbe, WO, Arasi, IA. Determination of appropriate mix ratios for concrete grades using Nigerian Portland-limestone grades 32.5 and 42.5. Leonardo Electronic Journal of Practices and Technologies, 2015; 1583-1078, p. 79-88.

[9] NIS 444-1 (2003). Cement: Composition, specifications and conformity criteria for common cements. Standards Organization of Nigeria.

[10] Tosun, K, Felekoğlu, B, Baradan, B, Altun, IA. Portland Limestone Cement Part I - Preparation of Cements. 2009; Digest, 1337-1355.

[11] Dhir, R, Limbachiya, M, McCarthy, M. Evaluation of Portland limestone cements for use in concrete construction. Mater Struct, 2007; 40:459-73.

[12] Adewole, KK, Olutoge, FA, Habib, H. Effect of Nigerian PortlandLimestone Cement Grades on Concrete Compressive Strength. International Journal of Civil and Environmental Engineering, 2014; Vol: 8, No: 11.

[13] Joel, M, Mbapuun, ID. Comparative analysis of the properties of concrete produced with Portland Limestone Cement (PLC) grade $32.5 \mathrm{~N}$ and 42.5R for use in Rigid Pavement Work. Global Journal of Engineering Research, 2016; 15. p. 17-25.

[14] IS 1489-2: (1991). Portland-Pozzolana Cement-Specification.

[15] Fapohunda, C, Famodimu, B, Adigo, B, Jeje, A. Effect of Changing Cement Grade on the Properties of Structural Concrete. Nigerian Journal of Technological Development, 2020; 17(3), 197-204.

[16] Oyenuga, V. 2014. Cement not Responsible for Building Collapse in Nigeria. An Editorial in This day Newspapers of 13th May 2014

[17] Hawkins, P, Tennis, PD, Detwiler, RJ. The Use of Limestone in Portland cement: A State-of-the-Art Review, Portland Cement Association, Skokie, Illinois, USA, 2003.

[18] Council for the Regulation of Engineering in Nigeria (COREN) (2017): Concrete mix design manual. Special Publication No. COREN/2017/016/RC

[19] Hodhod, H, Abdeen, MAM. Experimental Comparative and Numerical Predictive Studies on Strength Evaluation of Cement Types: Effect of Specimen Shape and Type of Sand. Engineering, 2010; 2. p.559-572.

[20] Mathur, R, Misra, AK, Goel, P. Strength of Concrete vs. Grades of Cement [Internet]. 2011 [updated 2020 June 23; cited 2020 December 6]; Available from: https://www.nbmcw.com/techarticles/concrete/25796-strength-of-concrete-vs-grades-ofcement.html.

[21] Kazeem, KA, Festus, AO, Hamzat, H. Effect of Nigerian PortlandLimestone cement grades on concrete compressive strength International Journal of Civil, Environmental, structural, Construction and Architectural Engineering, (2014); (11): 1140-1143.

[22] British Standards Institution. BS EN 933-2: (2020). Eurocode 3. Tests for geometrical properties of aggregates - Determination of particle size distribution. Test sieves, nominal size of apertures.

[23] British Standards Institution. BS EN 196-6: (2018). Eurocode 3. Methods of testing cement - Determination of fineness. British Standard Institution, London

[24] British Standards Institution. BS EN 12350-2: (2000). Eurocode 3. Method for Determination of slump. British Standard Institution, London.

[25] Baruah P, Talukdar SA. Comparative study of compressive, flexural, tensile and shear strength of concrete with fibres of different origins. Indian Concr J, 2007; 81(7):17-24.

[26] British Standards Institution. BS EN 12390-3: (2009). Eurocode 3. Testing Hardened Concrete: Compressive Strength of Test Specimens British Standard Institution, London.

[27] Oseni, O, Audu, T. Influence of Water Cement Ratio Variation on Properties of Millet Stem Ash (MSA) Concrete. International Journal of Science and Research (IJSR), 4(11), 2013; 1973-1978.

[28] Vu, X, Malecot, Y, Daudeville, L, Buzaud, E. Effect of the water/cement ratio on concrete behavior under extreme loading. International Journal for Numerical and Analytical Methods in Geomechanics, 2009; 33(17), 1867. 